\title{
Internationalisation and innovation on balanced scorecard (BSC) among Malaysian small and medium enterprises (SMEs)
}

\author{
Poh Ling Chong ${ }^{a^{*}}$, Tze San Ong ${ }^{a}$, Amalina Abdullah ${ }^{a}$ and Wei Chong Choo ${ }^{a}$
}

${ }^{a}$ Faculty of Economics and Management, Universiti Putra Malaysia, 43400 UPM Serdang, Selangor, Malaysia

\begin{tabular}{l}
\hline C H R O N I C L E \\
\hline Article history: \\
Received: April 22, 2019 \\
Received in revised format: April \\
282019 \\
Accepted: May 22, 2019 \\
Available online: \\
May 23, 2019 \\
\hline Keywords: \\
Internationalisation \\
Knowledge \\
Trust \\
Commitment \\
Opportunity development \\
Balanced scorecard \\
Small and Medium Enterprises \\
Malaysia
\end{tabular}

\section{A B S T R A C T}

\begin{abstract}
The purpose of this paper is to identify the relationship between the determinants of internationalisation and innovation on balanced scorecard (BSC) among Malaysian small and medium enterprises (SMEs). Internationalisation covers the dimensions of knowledge, trust, commitment and opportunity development, which can benefit the firm performance in Malaysia by increasing the involvement of SMEs in international business activities. A sample of 202 firms was considered for this study and Structural Equation Modelling (SEM) was used. The dimensions of knowledge, trust, commitment and opportunity development were observed to examine the proposed hypotheses. The results indicate that internationalisation as a whole; such as knowledge, trust, commitment and opportunity development played an important role in innovation and balanced scorecard among Malaysian SMEs. However, this also can solve the existing myth of a role in the internationalisation on innovation towards a balanced scorecard of SMEs in Malaysia because family businesses are a critical pillar of many Malaysian enterprises. Therefore, this research conveys an understanding to the owners and managers to quickly achieve innovation and balanced scorecard results. Finally, this study brings some conclusions to the policy makers and regulators as well.
\end{abstract}

\section{Introduction}

In Malaysia, Small and Medium Enterprises (SMEs) contributes significantly to the economy of the country, whereby according to the Department of Statistics Malaysia (2016), there are about 907,065 SMEs in Malaysia. This figure translates to 98.5 per cent of total business establishments in the country. In the meantime, internationalisation of business is essential for SMEs because it provides opportunities for the SMEs to grow and perform in the business world that is getting increasingly competitive. Countries which are highly involved in internationalisation business activities have proven to have better firm performance. According to the Flash Euro-barometer 421 Report (2015), the SMEs in the European Union (EU) contributed more than 99 per cent of the European businesses and provided 85 per cent of all new job opportunities. Furthermore, the final report of the Internationalisation of European SMEs (2016/2017) mentioned that more than 50 per cent of SMEs which are involved in internationalisation show an increasing turnover of revenue. Moreover, higher employment growth from 2015 to 2016 has also been reported among SMEs which are involved in internationalisation, whereby firms which carry

* Corresponding author.

E-mail address: pohlingchong@gmail.com (P. L. Chong) 
out internationalisation reported an increase of 10 per cent in employment rate compared with only 3 per cent for firms that do not carry out internationalisation.

On top of that, an environment which is not export encouraging will hinder the growth of SMEs. This can be seen in 2007 and 2008 when Malaysia faced a financial crisis that affected the overall gross domestic product (GDP) growth in 2009 severely (Department of Statistics, 2012). During the financial crisis, there were minimal internationalisation activities due to the low export rate. Therefore, it is precisely understood that internationalisation is a significant factor that can improve the performance of the Malaysian SMEs, but it is often being overlooked, and this causes an obstruction among the Malaysian SMEs. This can be seen by the low economic contribution of SMEs in Malaysia, where the SME's GDP to overall GDP is only 36.6 per cent in 2016 as reported by the Department of Statistics Malaysia and SME Corporation Malaysia.

Hence, the lack of internationalisation and innovation might be the reason for the low contribution. The Internationalisation of SMEs in Malaysia is adapted from the Revised Uppsala Internationalisation Process Model (RUIP Model), and Innovation is adapted from the Innovation Related Internationalisation Model (I-Model). Moreover, the SMEs internationalisation and innovation's relationship to firm performance, using BSC has not been conclusively found, and the contribution, as well as the empirical evidence of internationalisation to BSC, is still inadequate. This shows the common problems with Malaysian SMEs and this research is crucial to find out the relationship of internationalisation, innovation and BSC. Thus, the purpose of this paper is to examine further internationalisation and innovation of SMEs in Malaysia that will bring about better firm performance, measured by BSC.

\section{Literature Review}

The literature review can be viewed from two different perspectives; such as theoretical review and empirical review. This section discusses internationalisation, innovation and balanced scorecard in detail.

\subsection{Internationalisation}

Internationalisation is an obscure term that is clarified uniquely from research to research. As per Calof and Beamish (1995), it is 'the process of adopting firms' operations like strategy, structure, or resources into international environments". Welch and Luostarin (1988) defined internationalisation as the increasing involvement of the firm in international activities. As per Schweizer et al. (2010), it is where firm undertakings for better performance inside the network in global markets. There are a couple of entry modes accessible for the process of internationalisation or moving into an abroad market. Exporting is the conventional approach to enter the international market. SMEs regularly utilise this mode because they face issues of shortage of knowledge, experience and resources. For SMEs which suffer a lack of financial resources, licensing approach of entry is valuable. Licensing is the point at which a firm, called the licensor, leases the privilege to utilise its intellectual properties like technology, particular business skills, and brand names, to another firm, called the licensee, in return of a fee (Singh et al., 2010).

Joint ventures can be perceived as a transitory contract which empowers at least two parties to complete transactions (Dalle \& Potts, 1999) jointly. The obligations and privileges of individual parties, risk allocation, distribution of profits, and additionally dispute resolutions ought to be determined in a joint venture contract (Gale \& Luo, 2004). Besides, there are two sorts of the wholly owned subsidiary: Greenfield investment and Acquisitions. Greenfield investment is the foundation of another wholly owned subsidiary. Most of the time, it is complicated and possibly expensive, yet it can give full control to the firm and has the most potential to provide a better than expected return (Hitt et al., 2009). The acquisition can turn into the most substantial way of expanding into international business because of its fast access (Hitt et al., 2009; Oviatt \& McDougall, 1994, 1995). 


\subsubsection{The Revised Uppsala Internationalisation Process Model (RUIP-Model)}

This study is based on the RUIP Model, originated from the first Uppsala Internationalisation Model (UModel) published in 1977. Due to many changes in business practices and advances since 1977, the model has been revised several times (Johanson \& Mattsson, 1977, 1988, 1990; Johanson \& Vahlne, 2003, 2009). Specifically, the new model highlights the primary of networked businesses and interdependent relationships in the external international business environment (Johanson \& Vahlne, 2003, 2009). The new revised model does not observe a firm as a separate independent unit of analysis any longer but puts a great emphasis on the market and the network relationships between firms in the network (Johanson \& Vahlne, 2009). New knowledge is developed in these relationships whereby there is a potential for learning and for building trust and commitment, both of which are preconditions for internationalisation (Johanson \& Vahlne, 2009).

\subsection{Innovation}

Innovation can be defined as the successful conversion of new concepts and knowledge into new products, services, or processes that create value for a business firm. This may mean creating a new product, service, system, or process, or enhancing existing ones. In this era of internationalisation, when the world has come closer than ever before, it is more difficult for SMEs to perform well (Singh et al., 2010). Therefore, it is very challenging for the Malaysian SMEs to be unique in their products. One of the ways SMEs can boost their performance is through innovation (Cottam et al., 2001). Through the process of innovation, SMEs can create entirely new products that can bring them to a category of high-growth companies with an opportunity to be market leaders (Abbing \& Van Gessel, 2008). Therefore, such enterprises would have the upper hand to achieve superior firm performance (Autio et al., 2000). There are more than a dozen types of innovation, but the most popular types of innovations among SMEs are product, process and information technology innovations.

Product innovation refers to introducing new products and improving existing products (Chang \& Hughes, 2012; Polder et al., 2010). Product innovations can include mechanical and technological devices, scientific tools, architectural structures, and artistic masterpieces (Mars, 2013; Polder et al., 2010). Process innovation is intangible and has gained more importance recently (Lichtenthaler, 2011; Trott \& Hartmann, 2009; Van de Vrande et al., 2010). It involves a new or significantly improved production or delivery method of producing a product (OECD, 2005). Process innovation enhances the efficiency and productivity of production activities, increases quality and reduces the unit cost of production (Abdallah $\&$ Phan, 2007). Process innovation can adopt new and improved information technology (IT) to improve the performance of the firm. IT innovation involves using technology in new ways to create a more efficient firm and to improve the relationship between technology initiatives and business goals, and subsequently firm performance. For instance, it can be used to turn business processes into automated ecommerce functions, for example, Amazon.com, Alibaba.com, Lelong.com, E-bay, etc. Grandon and Pearson (2004) defined e-commerce as "the process of buying and selling products or services using electronic data transmission via the Internet". The increasing desire for consumer self-service, as well as the firm's goal for better performance, has been a channel for the use of technology innovation in today's business (Dabholkar et al., 2000; Hao \& Song, 2016; Meuter et al., 2000).

\subsubsection{The "Innovation-related Internationalisation Model" (I-Model)}

The Innovation-related model (I-Model) is another model in explaining the internationalisation of SMEs in Malaysia. This model takes into account the decision to internationalise as an innovation for the firm and emphasises on the learning steps related to adopting an innovation (Andersen, 1993). Moreover, this model describes internationalisation as a step-by-step development whereby each step represents more experience and greater involvement than the previous step. The Model also sees internationalisation as a procedure in which the means are parallel to that of another new product adoption (Rogers, 1962). This 
model is bolstered by some researchers (Bilkey \& Tesar, 1977; Cavusgil \& Godiwalla, 1982) who consider the choice of internationalisation as innovation for the firm and hence give another point of view of the improvement of a gradual process regarding internationalisation. For Bilkey and Teasar (1977), Cavusgil and Godiwalla (1982), each ensuing step of the process is an innovation for the firm. Therefore for the I-Model, internationalisation is considered a step by step as well as an innovation for the firm.

\subsubsection{Innovation as the Mediator}

Internationalisation and innovation are two strategic activities which are highly connected (Chebbi et al., 2017; Kylläheiko et al., 2011). By having internationalisation, companies will be more innovative. The literature finds that innovation and internationalisation are inextricably linked. While Aw et al. (2011) found that the marginal benefit of both internationalisation and innovation simultaneously increases with productivity, there is some evidence that internationalisation might drive product and process innovation (Cassiman \& Golovko 2011). In particular, firms that export their goods abroad are, on average, also more likely to have invested into innovation practices (Williams \& Shaw, 2011). At the same time, firms that have no international exposure are the ones that typically have not innovated recently (Altomonte et al., 2013). Therefore, if the firms are not innovative enough, they cannot compete internationally, they can operate in the local market only. Only in a competitive environment, firms can strive for the best. Companies which operate in other countries can learn from different innovation contexts and therefore can benefit from them (Filippetti et al., 2009). In this case, innovation is considered as a competitive advantage (Adalikwu 2011; Pla-Barber \& Alegre 2007), where companies compete on international markets for profitability, and innovation is considered as a vital source of firm performance. Companies, in general, tend to grow and make a profit by selling products or services to foreign countries (internationalisation), by inventing/creating new products, services (innovation) (Kriz \& Welch, 2018; Kylläheiko et al., 2011). Hence, when there is better innovation, it will increase firm performance. In other words, if all these are present, firm performance can be improved.

\subsection{Performance Evaluation via Balanced Scorecard (BSC)}

Performance evaluation can be implied via balanced scorecard (BSC), which is a performance measurement in detail used by any enterprise. Thus, BSC can be related to the firm performance of SMEs in Malaysia as well. Few researchers, such as Najafi et al. (2013), Birinci and Eren (2013) and Leelakusolvong (2009) noted that the firm performance is an integral part of the enterprise itself because this is the primary indicator where people can judge whether or not an enterprise is doing well. The firm performance can serve some functions as well as a few purposes. The measurement systems devoid of cause and effect judgment may also be eligible for the BSC (Moghaddam, 2012). It has become an accounting, finance and management instrument, typically utilising a stratagem plan to demonstrate the connection among measures and factors (Meyer et al., 2014; Morrisette \& Oberman, 2013; Speckbacher, 2003). In contrast, there is an observation in the literature (Morrisette \& Oberman, 2013) with the intention of the necessary implication of thought-out administration with performance management for the organisation, which is SMEs in this particular research.

Many SMEs are principally mission determined, and the BSC is centred on acquiring purpose while connecting jointly with the SME's perspective, it is an attractive and considerably significant strategic work out for SMEs while considering the firm performance. Niven (2008) recommended that the numerous aspects of the BSC be supposed to be measured in assessing firm performance. This is for a reason that information criticism gained as of these perspectives helps SMEs construct necessary adjustments the majority significant to the business achievement. Consequently, Kaplan (2001), Kaplan and Norton (1992a, 1992b, 1996, 2000, 2001), Luen et al. (2013) and Moghaddam, (2012) framed the BSC to gather contemporary dynamic business requirements through supplementing monetary evaluates with indicators beginning with the internal business process, innovation processes and organisation learning and growth processes. 
As a result, the BSC provides managerial guidance with comprehensive cross-functional frameworks from which they need to assess the organisational performance (Fang \& Lin, 2006; Kaplan \& Norton, 1992, 1996a, 1996b, 2001; Wang, 2006). According to Birinci and Eren (2013), the BSC was adapted to focus on the lack of profit motive within the SMEs. In the SMEs, the BSC can be applied to recognise the linkages among the goals and objectives and organisational outcomes. In this approach, it is projected (Kaplan \& Norton, 1996b; Leroux, 2005) that the BSC relations financial consequences with operational data thereby creating avenues to modify or line up operations with long-term enterprise goals, such as how the BSC has been adapted to measure the firm performance in the SMEs are addressed in the remainder of this segment (Kaplan \& Norton, 2000; Niven, 2008).

\subsection{Internationalisation (INT) and Innovation (INN)}

A number of articles have been published which highlight on internationalisation and innovation and their link to SMEs (Altomonte et al., 2013; De Jong \& Vermeulen, 2006; Ganotakis \& Love, 2010; Lin $\&$ Chen, 2007). The relevance of this relationship appears that firms that carry out internationalisation are likely to be able to adapt their innovation strategies to the foreign markets, and therefore the Innovation would be improved. Also, a few attempts have been made by past researches to study the impact of internationalisation on innovation, for example in the computer software industry (Chetty \& Stangl, 2010). Therefore, the link can be described as below.

$\mathrm{H}_{1}$ : Internationalisation (INT) is positively related to Innovation (INN).

\subsection{Internationalisation (INT) and Balanced Scorecard (BSC)}

According to Welch and Luostarinen (1988), internationalisation is a process whereby the firm increases its involvement in international markets. It is vital for SMEs in developing countries to internationalise due to increasing competitive pressure (Ahmad et al., 2010; Etemad, 1999, 2004). This is an indication of linkage between internationalisation and BSC which measures the firm performance, and the link can be portrayed as:

$\mathrm{H}_{2}$ : Internationalisation (INT) is positively related to Balanced Scorecard (BSC).

\subsection{Linkage of Innovation (INN) and Balanced Scorecard (BSC)}

Innovation is a new and advanced way of performing business activities. This innovative method of doing business is useful to create value for all parties that are involved in the whole business chain. Innovation activities are generally identified as an essential determinant of firm performance which is measured using the BSC to compete in the international market (Pla-Barber \& Alegre, 2007). Innovation helps create new means for firm performance by enhancing the relationship between internationalisation (knowledge, trust, commitment, opportunity development) and BSC. According to Chang and Hughes (2012) and Polder et al. (2010), product innovation means introducing new products and improving existing products. Successful product innovations, in particular, are a prerequisite of doing well in international markets because the value of the product is enhanced. There is also a relatively broad consensus that firms which introduce product innovations are more likely to export and therefore will bring to better firm performance (Polder et al., 2010; Hao \& Song, 2016). In a properly planned internationalised firm where the innovation is well cultivated, an adequate level of firm competitiveness and profitability is often seen, and therefore, SMEs may be able to reach their expected firm performance (Cassiman \& Golovko, 2011; Freel \& Robson 2004). Some past literature also highlighted innovation and firm performance along with their relationship in the SMEs context (Johannessen et al., 2001; Roper 1997; Storey 2016). With this evidence, therefore, it can be hypothesised as follows:

$\mathrm{H}_{3}$ : Innovation (INN) is positively related to the Balanced Scorecard (BSC). 

card (BSC)

This section presents the linkages between internationalisation to the mediator, innovation, and the possible effects to BSC, which is used to measure firm performance. This proposition deals with the effect of internationalisation on firm performance through the impact of innovation. Besides, the primary hypotheses, this current research also measures the mediating relationships among the variables. It has been found that innovation plays a significant role in a firm that practices internationalisation, whereby it will affect firm performance (Ganotakis \& Love, 2010). Furthermore, several studies show that firm performance also increases after entering a foreign market (Bausch \& Krist, 2007; Bustos, 2011; Damijan et al., 2010). By combining these two points, it can be hypothesised as follows:

$\mathrm{H}_{4}$ : Innovation (INN) mediates the relationship between elements of Internationalisation (INT) and Balanced Scorecard (BSC).

Derived from the literature support and related evidence, this concern puts a conceptual framework which is exhibited in Fig. 1.

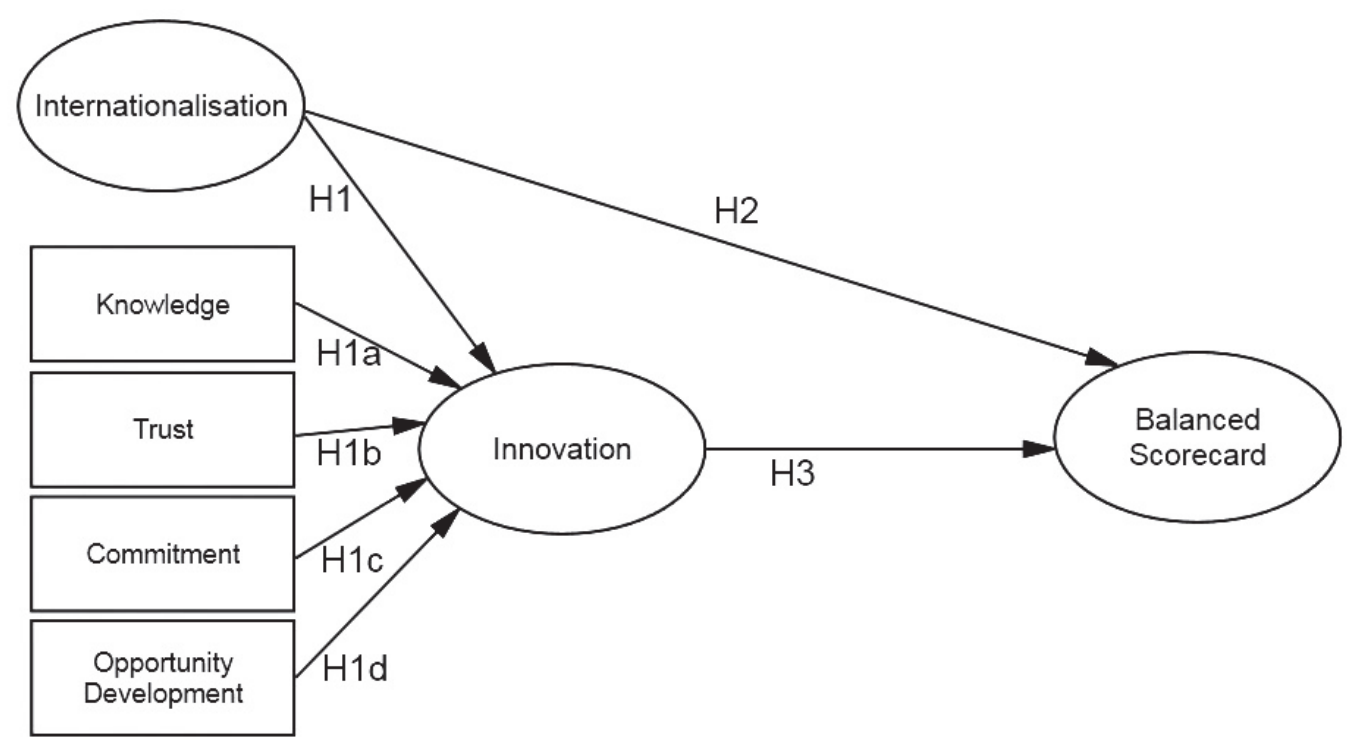

H4: Internationalisation => Innovation => Balanced Scorecard

Fig. 1. Research Framework

To meet the research objective and based on the conceptual framework presented above, four prominent hypotheses were constructed as discussed above. With all sub-hypotheses, those are presented below:

$\mathrm{H}_{1}$ : Internationalisation (INT) is positively related to Innovation (INN).

$\mathrm{H}_{1 \mathrm{a}}$ : Knowledge is positively related to Innovation (INN).

$\mathrm{H}_{1 \mathrm{~b}}$ : Trust is positively related to Innovation (INN).

$\mathrm{H}_{1 \mathrm{c}}$ : Commitment is positively related to Innovation (INN).

$\mathrm{H}_{1 \mathrm{~d}}$ : Opportunity Development is positively related to Innovation (INN).

$\mathrm{H}_{2}$ : Internationalisation (INT) is positively related to BSC.

$\mathrm{H}_{3}$ : Innovation (INN) is positively related to Balanced Scorecard (BSC).

$\mathrm{H}_{4}$ : Innovation (INN) mediates the relationship between elements of Internationalisation (INT) and Balanced Scorecard (BSC). 


\section{Research Methodology}

The research method of this study is the survey method. The survey method is the most appropriate method for the data collection as this method helps to predict the nature of the total population from which the sample is selected (Fowler, 1988; Sapsford, 1999). Survey research method often leads to achieve accuracy and relatively cost-efficient data for the research (Sekaran \& Bougie, 2016; Kothari, 2004). This method can be developed in less time and ability to collect data from a large number of respondents (Neuman, 2007). Besides, the unit of analysis in this study is the enterprise itself, and the respondents are business owners, entrepreneurs and managers who will represent the respective SME. The sampling frame in this study contains the SMEs that has internationalisation activities and are obtained from the directories of the Malaysia External Trade Development Corporate (MATRADE). For this purpose, the SMEs are chosen from the sampling frame representing the population and are grouped into two broad criteria:

i. The businesses that will be selected would fulfil the criteria of Small and Medium Enterprises (SMEs) in either the service sector or the manufacturing sector.

ii. The respondents who will take part in this study comprised of business owners, top management and entrepreneurs. These groups of people are chosen because they are knowledgeable about the operation of the business, including internationalisation aspect of the firm, the business network and aspect related to firm performance. The person should be involved in decision makings related to business networks, firm planning and implementation.

This research used a 7-point Likert scale for constructing the questionnaire by putting preferences for the items considered in past studies. Moreover, a 7-point Likert scale asked respondents to provide a relative assessment of various statements in the questionnaire on a continuum ranging from 'very strongly disagree' to 'very strongly agree' that are very commonly used for collecting primary data in empirical research (Ward et al., 1998). To meet the research objective, this study employed the stratified sampling technique to carry out the survey. Sekaran and Bougie (2016) stated that stratified random sampling involves a process of stratification or segregation, followed by a random selection of subjects from each stratum. Moreover, questionnaires were only distributed to respondents who met the above criteria. As this research employs Structural Equation Modelling (SEM), therefore the questions of sample size adequacy remained as a prime concern in the application of SEM software. A sample of 202 data was considered as the final sample size of the current study. As mentioned, this research employs SEM for statistical analysis of data, which is developed for analysing the interrelationships among multiple variables in a model (Zainudin, 2012). Besides, SEM techniques have been significant to confirm theoretical models for using a quantitative approach. Therefore, evaluating these circumstances, this study considers SEM as a suitable tool for analysing quantitative data in research progression.

\section{Findings}

This section begins with the demographic information of the respondents. The demographic data comprises of gender, age, race, level of education and designation of the respondents in the respective enterprise. Findings have revealed that both male and female were in good numbers participating in the study. Among 202 respondents, it is observed that 116 are male and 86 are female, which means the percentages of male and female respondents are 57.4 per cent and 42.6 per cent respectively. Besides, the age range of 41-50 years is 47.0 per cent and with the highest frequency of 95, and 31-40 years age range covers 44.1 per cent and having a second highest frequency of 89 out of 202. Additionally, the age range of 2120 years consists of 8.9 per cent with 18 respondents. Just like age diversity, there is also the diversity of races who are engaged in SMEs, where the engagement of Malay, Indian and Chinese are 27.6, 59.4 and 13.6 per cent respectively. Hence, the Chinese have a more significant percentage compared to Indians after Malays. Out of 202 respondents, about education level, 19 respondents ( 9.4 per cent) passed sec- 
ondary school, 60 respondents ( 29.7 per cent) hold a diploma, 93 respondents ( 46 per cent) have a bachelor degree, and only 30 respondents ( 15.1 per cent) were master degree holders. Out of these, 80 respondents (39.6 per cent) are managers, 68 respondents (33.9 per cent) are entrepreneurs, and 54 respondents (26.5 per cent) are owners among those 202 respondents. Apart from the demographic information, the enterprise information outlines an enterprise which is the background of the venture. In this particular study, the enterprise information indicates five major things covering types of business, number of employees, ownership, regional area and internationalisation activity.

On the other hand, the percentages of manufacturing and service industries are 14.9 per cent and 85.1 per cent respectively, where 30 enterprises are involved with manufacturing activities, and 172 enterprises are engaged with the service sector. There are 117 enterprises or 57.9 per cent which have 6-30 employees, 55 enterprises or 27.2 per cent have 31-75 employees, 24 enterprises or 11.9 per cent hire 76-200 employees, and 6 enterprises or 3.0 per cent hire only 0-5 employees. Besides that, it is found that 100 per cent of enterprises is Malaysian owned SMEs. Geographical area wise, most of the enterprises deal with countries in the South East Asia region, which consists of 157 enterprises or 77.7 per cent; the second highest region that is involved in the Asia region, with 26 enterprises or 12.9 per cent. The rest of the regions like Europe, Oceania and the America and the Middle East make up the rest of the regional areas which Malaysian SMEs have dealt with. Regarding internationalisation activity, the most popular activity among SMEs in Malaysia is export, which recorded 174 enterprises or 86.1 per cent, with import activity coming in second with 18 enterprises or 8.9 per cent. The rest are involved in licensing, franchising and joint venture. In this study, information analysis will be done in a few phases. In the main stage, the gathered information will be coded and gone into SPSS worksheet. Step two includes testing legitimacy, reliability and exploratory factor analysis (EFA) re-utilising SPSS. In stage three, promote measurable tests will be led, for example, confirmatory factor analysis (CFA), reliability, and legitimacy reutilising AMOS. The last step will re-utilise SEM for the model and theories testing. A progression of goodness-of-fit files that mirror the wellness of the model will be re-utilised in this study. Notwithstanding, there is no general understanding among the researchers concerning which wellness lists ought to be re-utilised (Zainudin, 2012). Hair et al. (2010) and Holmes-Smith and Coote (2006) suggested re-utilising somewhere around three relevant records including no less than one file from every class of fit model. In the Exploratory Factor Analysis (EFA), the estimating modelling has been finished by considering every one of the factors simultaneously with the end goal to confirm the suitability of the general model. Under this model, the covariance structure of all the concerned inactive elements was learned in the meantime. Therefore, the general measurement model was tried by joining all the idle factors together. This study also looked into the KMO and Barlett's Test of Sphericity value (Pallant \& Manual, 2007). The KMO value achieved in this study is .841 with a significant level of 0.000 . The outcomes of the tests are shown below in Table 1.

Table 1

KMO and Bartlett's Test

\begin{tabular}{llc}
\hline \multicolumn{2}{c}{ Kaiser-Meyer-Olkin Measure of Sampling Adequacy. } & .841 \\
\hline \multirow{3}{*}{ Bartlett's Test of Sphericity } & Approx. Chi-Square & $6.011 \mathrm{E} 3$ \\
& $\mathrm{df}$ & 561 \\
& Sig. & .000 \\
\hline
\end{tabular}

Besides, the reliability of a specific scale reveals the degree to which it is without random error (Pallant \& Manual, 2007) whereby, consistently measuring what it is supposed to measure (Hair et al., 2010), which means that reliability discloses the consistency of a particular research instrument. One of the most widely used approaches for testing reliability is known as Cronbach's alpha. Cronbach's alpha permits researchers to test internal consistency among the items included in the research instrument with values that fall between the range of 0 to 1 whereby, the higher the value, the higher the reliability (Pallant \& 
Manual, ,2007). At least a value ranging from 0.6 to 0.7 is required for the Cronbach's alpha to be considered acceptable (Hair et al., 2010). Thus, in order to investigate how reliable the questionnaire items are Cronbach's alpha was run. We can observe from Table 2 that the value attained for Cronbach's alpha is .819 , indicating that there is an adequate level of consistency among the items that are in the research instrument.

Table 2

Reliability Statistics

\begin{tabular}{|c|c|c|c|}
\hline & Variable & Cronbach's Alpha & $\mathrm{N}$ of Items \\
\hline \multirow{4}{*}{ 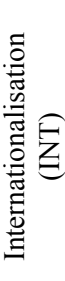 } & Knowledge & 0.825 & 4 \\
\hline & Trust & 0.814 & 4 \\
\hline & Commitment & 0.900 & 5 \\
\hline & Opportunity Development & 0.852 & 4 \\
\hline & Innovation (INN) & 0.889 & 5 \\
\hline & Balanced Scorecard (BSC) & 0.741 & 5 \\
\hline & Overall & 0.819 & 27 \\
\hline
\end{tabular}

Followed by EFA and CFA for all individual constructs, the measuring model has been executed by taking into account all the variables concurrently in order to verify the appropriateness of the overall model. Initially, all the items derived from EFA were included in the measurement model. Under this model, the covariance structure of all the concerned latent variables was studied at the same time. Thus, the overall measurement model was tested by combining all the latent variables. The findings demonstrates that the wellness level for the measurement model for this study is accomplished [Incremental fit $(\mathrm{CFI})=.960,(\mathrm{GFI})=.942$; Parsimonious fit $(\mathrm{CMINDF})=2.873$; and Absolute fit $(\mathrm{RMSEA})=.041)]$. Subsequently, this study expects that the unidimensionality for the measurement model has been accomplished (Kline, 2011; Zainudin, 2012). No further adjustment was required for this model. After the fitness of the measurement, the model has been attained it is essential to report the parameter estimates. According to Zainudin (2012), every researcher must observe the unidimensionality, validity and reliability. Hence, to achieve the discriminant validity, measurement modelling for the constructs are combined to check inters variable correlation value. If the path value between two constructs is higher than 0.85, this proofs that the discriminant validity has failed to achieve the required value (Byrne, 2010). Thus, the model is wrong. Table 3 shows the correlation among the study constructs, and none of the path value is higher than 0.85 . As a result, this certifies the discriminant validity of the measurement model.

Table 3

Inter Item Correlations

\begin{tabular}{llll}
\hline Inter Item Correlations & & & Estimate \\
\hline Internationalisation & $\leftrightarrow$ & Innovation & .624 \\
Internationalisation & $\leftrightarrow$ & Balanced Scorecard & .441 \\
Innovation & $\leftrightarrow$ & Balanced Scorecard & .370 \\
\hline
\end{tabular}

Moreover, this study concludes that all the CFA results conducted passed the unidimensionality, validity as well as reliability for further analysis. Table 4 summarizes the findings of the CFA results. All the hypotheses of this study have been tested through the application of SEM. For the overall model as a whole, the statistical result indicates a good fit. The complete model inclusive of the several hypothesised 
paths is illustrated in Table 5. From the model, it can be seen that all the variables uphold a positive value.

Table 4

CFA Results for the Measurement Models

\begin{tabular}{|c|c|c|c|}
\hline & Name of Category & Required Value & Comments \\
\hline & Unidimensionality & Factor loading for each item $\geq 0.50$ & The required level is achieved \\
\hline \multirow{3}{*}{ 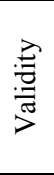 } & Convergent Validity & Average Variance Extracted (AVE) $\geq 0.50$ & The required level is achieved \\
\hline & Construct Validity & $\begin{array}{l}\text { All fitness indexes for the models meet the } \\
\text { required level }\end{array}$ & The required level is achieved \\
\hline & Discriminant Validity & $\begin{array}{l}\text { The correlation between exogenous con- } \\
\text { structs is } \leq 0.85\end{array}$ & The required level is achieved \\
\hline \multirow{3}{*}{ 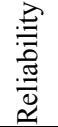 } & Internal Trust & Cronbach alpha $\geq 0.70$ & The required level is achieved \\
\hline & Construct Trust & $\mathrm{CR} \geq 0.60$ & The required level is achieved \\
\hline & Average Variance Extracted (AVE) & $\mathrm{AVE} \geq 0.50$ & The required level is achieved \\
\hline
\end{tabular}

\section{Table 5}

Hypothesis Testing

\begin{tabular}{lclcccc}
\hline & & & Estimate & S.E. & C.R. & P \\
\hline Innovation & $\leftarrow$ & Knowledge & 0.412 & 0.210 & 1.962 & $* * *$ \\
Innovation & $\leftarrow$ & Trust & 0.334 & 0.134 & 2.493 & $* * *$ \\
Innovation & $\leftarrow$ & Commitment & 0.350 & 0.152 & 2.303 & $* * *$ \\
Innovation & $\leftarrow$ & Opportunity Development & 0.545 & 0.253 & 2.154 & $* * *$ \\
Innovation & $\leftarrow$ & Internationalisation & 0.711 & 0.308 & 2.308 & $* * *$ \\
Balanced Scorecard & $\leftarrow$ & Internationalisation & 0.778 & 0.365 & 2.132 & $* * *$ \\
Balanced Scorecard & $\leftarrow$ & Innovation & 0.484 & 0.181 & 2.674 & $* * *$ \\
\hline
\end{tabular}

Table 5 shows that the p-value is less than $0.05(0.000)$ for all cases with an acceptable estimate value and standard error; as such, the regression weight for all exogenous variable is significantly different from zero at the 0.01 level. Another thing to be noted, all the C.R. value is more than 1.96; thus, all hypotheses are accepted with the p-value of high significance. For that, the mediating analysis has been proven supported as well. More specifically, this is a partial mediation. After this, by looking at the values presented in Table 5, the summary of the main findings of the study can be presented in Table 6 .

\section{Table 6}

Summary of the Main Findings of the Study

\begin{tabular}{llc}
\hline H(x) & Hypothesis & Finding \\
\hline H1 & Internationalisation (INT) is positively related to Innovation (INN) & Accepted \\
H1a & Knowledge is positively related to Innovation (INN) & Accepted \\
H1b & Trust is positively related to Innovation (INN) & Accepted \\
H1c & Commitment is positively related to Innovation (INN) & Accepted \\
H1d & Opportunity Development is positively related to Innovation (INN) & Accepted \\
H2 & Internationalisation (INT) is positively related to BSC & Accepted \\
H3 & Innovation (INN) is positively related to Balanced Scorecard (BSC) & Accepted \\
H4 & Innovation (INN) mediates the relationship between elements of Internationalisation & Accepted \\
\hline
\end{tabular}

\section{Discussion and Conclusions}

This study has been an attempt to assess the internationalisation for the firm performance which is measured using BSC of SMEs in Malaysia. The BSC is a measure of efficiency, which is indicated by profitability and productivity due to its reflection on how well the firm can translate its demands in the market 
into products that generate profits. This study has attempted to assess the relationship of Knowledge, Trust, Commitment, Opportunity Development and overall Internationalisation, as well as Innovation towards BSC as a measuring tool for firm performance for the Malaysian SMEs. The findings of the study may provide some implications in Malaysian SMEs. The hypotheses support the relationship between Internationalisation and Innovation. Therefore, the hypothesised statement of H1 has been supported. It can also be expressed that the regression weight for Internationalisation in the prediction of Innovation is significantly different from zero at the 0.05 level (two-tailed). This indicates that Internationalisation has a significant favourable influence on Innovation for SMEs perspective in Malaysia. This is being supported by precedent works of literature where the many authors (Altomonte et al., 2013; Ganotakis \& Love, 2010) emphasized that the internationalisation of the practitioners influences the innovation.

Consequently, the relationship between Trust and Innovation confirms an adequate relationship. The results indicate that Trust had a significant favourable influence on Innovation for SMEs in the Malaysian perspective. Therefore, the hypothesised statement of $\mathrm{H} 1 \mathrm{~b}$ is supported. This is in-line with past literature like Hormiga and García-Almeida (2016) that emphasised that trust is an input for innovation. Table 5 exhibits that the relationship between Commitment and Innovation supports for the hypothesis, whereby it indicates that Commitment has a significant favourable influence on Innovation for SMEs perspective in Malaysia. Therefore, the hypothesised statement of $\mathrm{H} 1 \mathrm{c}$ is supported. The findings from past literature where Morgan and Hunt (1994) found that trust is a requirement for commitment, and since the trust was supported as mentioned, therefore commitment is also supported.

Furthermore, the relationship between Opportunity Development and Innovation has been supported by the hypothesis. Therefore, the hypothesised statement of H1d is supported. This is in line with past studies like Lin et al. (2012) which mentioned that if opportunity development is enhanced, that will bring about innovation. The next hypothesis has been tested to determine the relationship between Internationalisation and Balanced Scorecard. This has expressed an acceptable result that can be specified by Critical Ratio (C. R.) and significance level. Therefore, it can be said that the regression weight for Internationalisation in the prediction of BSC is significantly different from zero at the 0.05 level (two-tailed). Hence, the hypothesised statement of $\mathrm{H}_{2}$ is supported. Moreover, the findings attained from past results (Bell et al., 2003; Ruzzier et al., 2006; Westhead et al., 2001) showed the support of internationalisation towards BSC. The subsequent hypothesis has been tested, and Table 5 identifies that the relationship between Innovation (INN) and Balanced Scorecard (BSC) expresses a reasonable result. The findings accomplished from the result are in the same manner being maintained by scholarly perspective works where the numbers of authors (Albors-Garrigós et al., 2014; Kossai \& Piget, 2014) stated that innovation is leading to BSC which is used to measure firm performance. Thus, the hypothesised statement of $\mathrm{H} 3$ is supported.

Finally, the last hypothesis has been tested; the hypothesis of Innovation (INN) mediates the relationship between elements of Internationalisation (INT) and Balanced Scorecard (BSC) is supported. For this reason, a right mediation exists between Internationalisation (INT) and Balanced Scorecard (BSC) when Innovation (INN) is a mediator. In the Malaysian case, internationalisation is very much related to the innovation for SMEs (Altomonte et al., 2013) and play as input for BSC (Ganotakis \& Love, 2010). This justifies the connection between internationalisation and innovation. On the other hand, the SMEs can attain expected BSC if the innovation is executed correctly (Lins et al., 2016; Lin et al., 2012). Therefore, the hypothesised statement of $\mathrm{H}_{4}$ is supported. As a conclusion, there is a dearth of empirical studies previously conducted highlighting the internationalisation for BSC to measure the firm performance of Malaysian SMEs. As an empirical study, this research added value to the current level of knowledge in the existing literature on the internationalisation of Malaysian SMEs in the Malaysian context, both academically and empirically. This systematic assessment of structural relationships among the constructs facilitates a clearer understanding of the nature of the internationalisation of SMEs and how it can further 
contribute up to the firm performance. Predominantly, this particular study has identified a few critical dimensions of the firm performance of SMEs in Malaysia.

Precedent literature does not show that the internationalisation can be measured in term of BSC means. Thus, this study has also provided a measurement tool for determining SMEs firm performance. As a result, this research also helps different SMEs create sustainable and competitive advantages, and helps the SMEs people in recognising the proper internationalisation strategies as well as formulating special internationalisation techniques. This study has made a significant contribution to the theory, whereby this study considers the idea from a variety of theories such as the Revised Uppsala Internationalisation Process Model (RUIP-Model) and others, which are very likely to express the enterprises' business process, learning and growth, financial as well as customer perspectives. It brings a new recognition in academic research. Besides that, this study has also contributed to a methodology where sophisticated statistical analyses, structural equation modelling (SEM) were applied to analyse the data. Lastly, this study has also contributed to policymakers and regulators where it will help to identify the requirements and solutions for finding out the policy to strengthen the enterprise and maximise productivity and sustainable development. This will increase the efficiency which would be the final step for performance for any business, as to SMEs in Malaysia. Furthermore, this research conveys an understanding to the entrepreneurs regarding the internationalisation items; those that are more essential and play as the remedy swiftly achieve firm performance.

Nevertheless, some limitations need to be taken into account. The main limitation of this study was to get the required data. The respondents of this study were the enterprise owners and managers where we are not willing to participate in the survey. Besides, the language barrier was also found as a limitation. So, translating the questionnaire in the local language is recommended for future research. Additionally, 202 questionnaires were taken as the number of respondents, and this sample size may express an insufficiency regarding whole Malaysia perspective. This limitation took place because of the time constraint and budget limitation. Therefore, a more significant number of respondents are recommended for better findings.

\section{References}

Abbing, E. R., \& Gessel, C. V. (2008, April). Brand driven innovation: A practical approach to fulfill brand promise through product innovation. In International DMI Education Conference (Vol. 14, No. 15, pp. 1-25).

Abdallah, A., \& Phan, C. A. (2007). The relationship between just-in-time production and human resource management, and their impact on competitive performance. Yokohama Business Review, 28(2), 27-57.

Adalikwu, C. (2011). Impact of international and home-based research and development (R\&D) on innovation performance. International Journal of Human Sciences, 8(2), 474-498.

Ahmad, N. H., Ramayah, T., Wilson, C., and Kummerow, L. (2010). Are entrepreneurial competency and business success relationship contingent upon the business environment? A study of Malaysian SMEs. International Journal of Entrepreneurial Behaviour \& Research, 16(3), 182-203.

Albors-Garrigós, J., Rincon-Diaz, C. A., \& Igartua-Lopez, J. I. (2014). Research technology organisations as leaders of R\&D collaboration with SMEs: role, barriers and facilitators. Technology Analysis \& Strategic Management, 26(1), 37-53.

Altomonte, C., Aquilante, T., Békés, G., \& Ottaviano, G. I. (2013). Internationalization and innovation of firms: evidence and policy. Economic Policy, 28(76), 663-700.

Anderson, J. C. \& Gerbing, D. W. (1988). Structural equation modelling in practice: A review and recommended a two-step approach. Psychological Bulletin, 103, 411-423.

Andersen, O. (1993). On the internationalization process of firms: A critical analysis. Journal of international business studies, 24(2), 209-231.

Argyris, C. and Schon, D. (1996), Organisational Learning II: Theory, Method and Practice, Addison- 
Wesley, Reading, MA.

Autio, E., Sapienza, H. J., \& Almeida, J. G. (2000). Effects of age at entry, knowledge intensity, and imitability on international growth. Academy of management journal, 43(5), 909-924.

Bausch, A., \& Krist, M. (2007). The effect of context-related moderators on the internationalizationperformance relationship: Evidence from meta-analysis. Management international review, 47(3), 319-347.

Birinci, M., \& Eren, E. (2013). The Effect of Strategic Management Practices on the Performance of Universities in Turkey. Journal of Global Strategic Management, 13, 17-33.

Bilkey, W. J., \& Tesar, G. (1977). The export behavior of smaller-sized Wisconsin manufacturing firms. Journal of International Business Studies, 8(1), 93-98.

Bustos, P. (2011). Trade liberalization, exports, and technology upgrading: Evidence on the impact of MERCOSUR on Argentinian firms. American Economic Review, 101(1), 304-40.

Byrne, B. M. (2010). Structural Equation Modelling with AMOS: Basic Concepts, Applications, and Programming ( $2^{\text {nd }}$ ed). New York: Routledge.

Calof, J. L. and P.W. Beamish, (1995), Adapting to Foreign Markets: Explaining Internationalisation, International Business Review, 4(2), 115-131.

Cavusgil, S. T., \& Godiwalla, Y. M. (1982). Decision-making for international marketing: a comparative review. Management Decision, 20(4), 47-54.

Cassiman, B., \& Golovko, E. (2011). Innovation and internationalization through exports. Journal of International Business Studies, 42(1), 56-75.

Chang, Y. Y., \& Hughes, M. (2012). Drivers of innovation ambidexterity in small-to medium-sized firms. European Management Journal, 30(1), 1-17.

Chebbi, H., Yahiaoui, D., \& Thrassou, A. (2017). Multi-country collaborative innovation in the internationalisation process. International Marketing Review, 34(1), 109-137.

Chetty, S. K., \& Stangl, L. M. (2010). Internationalization and innovation in a network relationship context. European Journal of Marketing, 44(11/12), 1725-1743.

Cottam, A., Ensor, J., \& Band, C. (2001). A benchmark study of strategic commitment to innovation. European Journal of Innovation Management, 4(2), 88-94.

Dabholkar, P. A., Shepherd, C. D., \& Thorpe, D. I. (2000). A comprehensive framework for service quality: an investigation of critical conceptual and measurement issues through a longitudinal study. Journal of retailing, 76(2), 139-173.

Dalle, G., \& Potts, K. (1999). Joint ventures in the construction industry. A Paper presented at the Annual Workshop, School of Engineering and the Built Environment, University of Wolverhampton, UK Gaeton, D. and Keith, P. 1999.

Damijan, J. P., Kostevc, Č., \& Polanec, S. (2010). From innovation to exporting or vice versa?. World Economy, 33(3), 374-398.

De Jong, J. P., \& Vermeulen, P. A. (2006). Determinants of product innovation in small firms: A comparison across industries. International Small Business Journal, 24(6), 587-609.

Etemad, H. (1999). Globalisation and small and medium-sized enterprises: Search for potent strategies. Journal of Global Focus, 11(3), 85-105.

Etemad, H. (2004) Internationalisation of small and medium-sized enterprises: A grounded research framework and an overview, Canadian Journal of Administrative Sciences, 21(1), 1-4.

Fang, M. \& Lin, F. (2006). Measuring the performance of ERP system-from the Balanced scorecard perspective. Journal of American Academy of Business, 10(1), 256-263.

Filippetti, A., Frenz, M., \& Ietto-Gillies, G. (2011). Are innovation and internationalization related? An analysis of European countries. Industry and Innovation, 18(5), 437-459.

Fowler, F. J. (1988). Survey research methods. California: Newbury Park, Sage.

Freel, M. S., \& Robson, P. J. (2004). Small firm innovation, growth and performance: Evidence from Scotland and Northern England. International Small Business Journal, 22(6), 561-575.

Gale, A., \& Luo, J. (2004). Factors affecting construction joint ventures in China. International Journal of Project Management, 22(1), 33-42.

Ganotakis, P., \& Love, J. H. (2010). R\&D, product innovation, and exporting: evidence from UK new 
technology based firms. Oxford Economic Papers, 63(2), 279-306.

Grandon, E. E., \& Pearson, J. M. (2004). Electronic commerce adoption: an empirical study of small and medium US businesses. Information \& management, 42(1), 197-216.

Hair, J. F., Black, W. C., Babin, B. J. and Anderson, R. E. (2010). Multivariate Data Analysis: A Global Perspective ( $7^{\text {th }}$ Global ed.). Upper Saddle River: Pearson Prentice-Hall.

Hao, S., \& Song, M. (2016). Technology-driven strategy and firm performance: Are strategic capabilities missing links?. Journal of Business Research, 69(2), 751-759.

Hitt, M. A., Tihanyi, L., Miller, T., \& Connelly, B. (2006). International diversification: Antecedents, outcomes, and moderators. Journal of Management, 32(6), 831-867.

Holmes-Smith, C. E. \& Coote, L.(2006). Structural Equation Modelling: From the fundamentals to advanced topics.

Hormiga, E. and García-Almeida, D. L. (2016). Accumulated knowledge and innovation as antecedents of reputation in new ventures. Journal of Small Business and Enterprise Development, 23(2), 428 452.

Johanson, J., \& Mattsson, L. (1988). Internationalisation in industrial systems: a network approach. In Buckley, P.J. and Ghauri, P.N. (Eds), The Internationalisation of the Firm: A Reader, Academic Press, London, 303-21.

Johanson, J., \& Vahlne, J.-E. (2003). Building a model of firm internationalisation. In Blomstermo, A. and Sharma, D.D. (Eds), Learning in the Internationalisation Process of Firms, New Horizons in International Business, Edward Elgar, UK.

Johanson, J., \& Vahlne, J-E. (1977). The internationalisation process of the firm: a model of knowledge development and increasing foreign market commitments. Journal of International Business Studies, $8(1), 23-32$.

Johanson, J., \& Wiedersheim-Paul, F. (1975). The internationalisation of the firm four-Swedish cases. In Buckley, P.J. and Ghauri, P.N. (Eds), TheInternationalisation of the Firm (Published in 1999), International Thomson Publication, London.

Johanson, J., \& Mattsson, L. G. (1987). Interorganisational relations in industrial systems: a network approach compared with the transaction-cost approach. International Studies of Management \&Organisation, 17(1), 34-48.

Johanson, J., \& Vahlne, J. E. (1990). The mechanism of internationalisation. International Marketing Review, 7(4).

Johannessen, J. A., Olsen, B., \& Lumpkin, G. T. (2001). Innovation as newness: what is new, how new, and new to whom?. European Journal of Innovation Management, 4(1), 20-31.

Johanson, J., \& Vahlne, J. E. (2009). The Uppsala internationalisation process model revisited: From liability of foreignness to liability of outsidership. Journal of international business studies, 40(9), 1411-1431.

Kaplan, R. S. (2001). Strategic performance measurement and management in nonprofit organizations. Nonprofit Management and Leadership, 11(3), 353-370.

Kaplan, R. S., \& Norton, D. P. (1996). The balanced scorecard: translating strategy into action. Harvard Business Press.

Kaplan, R. S., \& Norton, D. P. (2004). Strategy maps: Converting intangible assets into tangible outcomes. Harvard Business Press.

Kaplan, R. S., \& Norton, D. P. (2007). Using the balanced scorecard as a strategic management system. Harvard business review, 85(7-8).

Kaplan, R. S., \& Norton, D. P. (1992). The balanced scorecard - measures that drive performance. Harvard Business Review, 70(1), 71-79.

Kaplan, R., \& Norton, D. (1992). The balanced scorecard: Measures that drive performance. Harvard Business Review, 83(7/8), 172-180.

Kaplan, R., \& Norton, D. (1996a). Linking the balanced scorecard to strategy. California Management Review, 39(1), 53-79.

Kaplan, R., \& Norton, D. (1996b). Using the balanced scorecard as a strategic management system. Harvard Business Review, 74(1), 75-85. 
Kaplan, R., and Norton, D. (2000). Having trouble with your strategy? Then map it. Harvard Business Review, 78(5), 167-176.

Kaplan, R., and Norton, D. (2001). Transforming the balanced scorecard from performance measurement to strategic management: Part II. Accounting Horizons, 15(2), 147-160.

Kline, R. B. (2011). Principles and practice of structural equation modelling (3rd ed.). New York: Guilford Press.

Kossaï, M., \& Piget, P. (2014). Adoption of information and communication technology and firm profitability: Empirical evidence from Tunisian SMEs. The Journal of High Technology Management Research, 25(1), 9-20.

Kothari, C. R. (2004). Research Methodology: Methods and Techniques (2 ${ }^{\text {nd }}$ ed.). New Delhi: New Age International Publishers.

Kylläheiko K., A. Jantunen, K. Puumalainen, S. Saarenketo and A. Tuppura. (2011).Innovation and internationalization as growth strategies: The role of technological capabilities and appropriability. International Business Review, 20, 508-520.

Lee, J.-N. (2001). The impact of knowledge sharing, organisational capability and partnership quality on IS outsourcing success. Information \& Management, 38, 323-35.

Leelakusolvong, V. (2009). Strategic Management and Organizational Effectiveness: A Case Study of Energy Group of Public Company in Thailand. Unpublished Dissertation. School of Public Administration. National Institute of Development Administration. Thailand.

LeRoux, K. M. (2005). What drives nonprofit entrepreneurship? A look at budget trends of metro Detroit social services agencies. American Review of Public Administration, 35(4), 350-362.

Lins, S., Schneider, S., \& Sunyaev, A. (2016). Trust is good, control is better: Creating secure clouds by continuous auditing. IEEE Transactions on Cloud Computing, 6(3), 890-903.

Lichtenthaler, U. (2011). Open innovation: Past research, current debates, and future directions. Academy of management perspectives, 25(1), 75-93.

Luen, W.K., Yong, K.T., \& Fook, O.S. (2013). Strategic planning and business performance: A study of SMEs in Malaysia. Proceedings of 3rd Asia-Pacific Business Research Conference, 25 -26 February 2013.Kuala Lumpur, Malaysia.

Mars, M. M. (2013). Building toward a holistic model of innovation and entrepreneurship education: transformation before commercialization. In A Cross-Disciplinary Primer on the Meaning and Principles of Innovation (pp. 113-124). Emerald Group Publishing Limited.

Meuter, M. L., Ostrom, A. L., Roundtree, R. I., \& Bitner, M. J. (2000). Self-service technologies: understanding customer satisfaction with technology-based service encounters. Journal of marketing, 64(3), 50-64.

Meyer, R. E., Egger-Peitler, I., Höllerer, M. A., \& Hammerschmid, G. (2014). Of bureaucrats and passionate public managers: institutional logics, executive identities, and public service motivation. Public Administration, 92, 861-885.

Moghaddam, T. (2012). The role of balanced scorecard implementation on financial performance transparency. Life Science Journal, 9(4), 3963-3970.

Morgan, R. M., \& Hunt, S. D. (1994). The commitment-trust theory of relationship marketing. Journal of marketing, 58(3), 20-38.

Morrisette, S., \& Oberman, W. (2013). Shifting strategic imperatives: A stages of leadership perspective on the adoption of corporate entrepreneurship. Journal of Applied Management and Entrepreneurship, $18(2), 59-82$.

Najafi Tavani, S., Sharifi, H., \& S. Ismail, H. (2013). “A study of contingency relationships between supplier involvement, absorptive capacity and agile product innovation", International Journal of Operations \& Production Management, 34(1), 65-92.

Neuman, W. L. (2007). Basic of Social Research: Qualitative and Quantitative Approaches (2 ${ }^{\text {nd }}$ ed.). New York: Pearson Education, Inc.

Niven, P. R. (2008). The balanced scorecard is step-by-step for government and nonprofit agencies (2nd ed.). Hoboken, NJ: John Wiley and Sons. 
Oviatt, B. M., \& McDougall, P. P. (1995). Global start-ups: Entrepreneurs on a worldwide stage. Academy of Management Perspectives, 9(2), 30-43.

Oviatt, B.M., \& McDougall, P. (1994). Towards a theory of international new venture. Journal of International Business Studies, 25(1), 40-64.

Pallant, J., \& Manual, S. S. (2007). A step by step guide to data analysis using SPSS for windows version 15. SPSS Survival manual, 3.

Pla-Barber, J., \& Alegre, J. (2007). Analysing the link between export intensity, innovation and firm size in a science-based industry. International Business Review, 16(3), 275-293.

Polder, M., Leeuwen, G. V., Mohnen, P., \& Raymond, W. (2010). Product, process and organizational innovation: drivers, complementarity and productivity effects.

Roper, S. (1997). Product innovation and small business growth: a comparison of the strategies of German, UK and Irish companies. Small Business Economics, 9(6), 523-537.

Ruzzier, M., Hisrich, R. D., \& Antoncic, B. (2006). SME internationalization research: past, present, and future. Journal of Small Business and Enterprise Development, 13(4), 476-497.

Sapsford, R. (1999). Survey Research. London: Sage.

Schweizer, R., Vahlne, J. E., \& Johanson, J. (2010). Internationalization as an entrepreneurial process. Journal of International Entrepreneurship, 8(4), 343-370.

Sekaran, U. and Bougie, R. (2016). Research methods for business: a skill-building approach (7thed.). Haddington: John Wiley \& Sons.

Singh, R. Pathak Kota, H. B. and Naz (2010). A resource dependency framework for innovation and internationalisation of family business: Evidence from India. Journal of Entrepreneurship in Emerging Economies, 9(2), 207-231.

Speckbacher, G. (2003). The economics of performance management in nonprofit organizations. Nonprofit Management and Leadership, 13(3), 267-281.

Storey, D. J. (2016). Understanding the small business sector. Routledge.

Van de Vrande, V., Vanhaverbeke, W., \& Gassmann, O. (2010). Broadening the scope of open innovation: past research, current state and future directions.

Wang, C., Hong, J., Kafouros, M., \& Wright, M. (2012). Exploring the role of government involvement in outward FDI from emerging economies. Journal of International Business Studies, 43(7), 655-676.

Ward, P. T., McCreery, J. K., Ritzman, L. P., \& Sharma, D. (1998). Competitive priorities in operations management. Decision Sciences, 29(4), 1035-1046.

Welch, L., Luostarinen, R. (1988). Internationalisation: evolution of a concept, Journal of General Management, 14(2), 34-64.

Westhead, P., Wright, M., \& Ucbasaran, D. (2001). The internationalization of new and small firms: A resource-based view. Journal of Business Venturing, 16(4), 333-358.

Williams, A. M., \& Shaw, G. (2011). Internationalization and innovation in tourism. Annals of tourism research, 38(1), 27-51.

Yeh-Yun Lin, C., \& Yi-Ching Chen, M. (2007). Does innovation lead to performance? An empirical study of SMEs in Taiwan. Management Research News, 30(2), 115-132.

Zainudin, A. (2012). A Handbook on SEM: Structural Equation Modelling Using Amos Graphics (4 ${ }^{\text {th }}$ ed.). Kelantan: University Technology MARA Press.

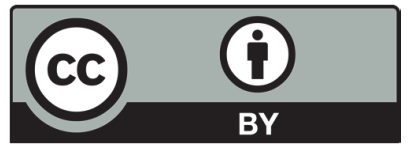

(C) 2019 by the authors; licensee Growing Science, Canada. This is an open access article distributed under the terms and conditions of the Creative Commons Attribution (CCBY) license (http://creativecommons.org/licenses/by/4.0/). 